\title{
Judge, Jurist and Legislature
}

The Right Hon. Lord Goff*

After he had despatched Augustine, with several other God-fearing monks, to preach the word of God to the English nation in the year 582, Pope Gregory the Great received from St Augustine from time to time reports of his progress and requests for guidance. Nineteen years later, in the year 601, he sent to Augustine a letter in which he granted to him the privilege of wearing the pallium when performing the solemnities of the Mass; and, after the messenger bearing that letter had departed from Rome, he sent another letter communicating further thoughts which, as Bede records, showed "most clearly his unwearying interest in the salvation of our nation." I quote from the letter:

"We have been giving careful thought to the affairs of the English and have come to the conclusion that the temples of the idols among that people should on no account be destroyed. The idols are to be destroyed, but the temples themselves are to be aspersed with holy water, altars set up in them, and relics deposited there ... In this way, we hope that the people, seeing that their temples are not destroyed, may abandon their error and, flocking more readily to their accustomed resorts, may come to know and adore the true God ... They are no longer to sacrifice beasts to the Devil, but they may kill them for food to the praise of God, and give thanks to the Giver of all gifts for the plenty they enjoy. If the people are allowed some worldly pleasures in this way, they will more readily come to desire the joys of the spirit. For it is certainly impossible to eradicate all errors from obstinate minds at one stroke, and whoever wishes to climb to a mountain top, climbs gradually step by step, and not in one leap..."

I quote these passages from Pope Gregory's letter to St Augustine, because they illustrate two qualities which I, for myself, particularly admire - his pragmatism and his gradualism. His approach can be most usefully contrasted with that of the Moghul Emperor who, after conquering the city of Mathura, caused a large

${ }^{*}$ Lord of Appeal in Ordinary. The Child \& Co. Oxford Lecture 1986, reprinted by kind permission of Lord Goff and Child \& $\mathrm{Co}$. 
mosque to be built on the site of the prison cell venerated by Hindus as the birthplace of the Lord Krishna - an act which causes offence to this day, though the Hindus now venerate a spot just outside the mosque which, they claim, was the actual site of the prison cell. But my purpose is not to condemn the jack-boot policy of the Moghul Emperor; it is to acclaim pragmatism and gradualism as the sovereign virtues, not only of Pope Gregory the Great, but also of the common law.

The history of the common law is a history of continuous, gradual, development over a period of many centuries. Of course, under the pressure of economic, political and social developments, the tempo of change has increased dramatically over the past 150 years, and is still increasing today. However, for the greater part of our history, the main instruments in the process of legal development were the judges together with the Chancellor; it is to them that we owe the majority of the fundamental legal principles which provide the framework within which we work today. It is only in the past 150 years or so, and especially since the Second World War, that the legislature has become increasingly active; but the nature of modern legislation is such that, to a surprising degree, the fabric of legal principle has remained untouched, with the result that its gradual development in the Courts has continued unabated.

If we are prepared to take the long perspective, we must recognise not merely the capacity of the law to change without the intervention of the legislature, but the absolute necessity that it should do so. Moreover, if we compare the law as it is today with the law as it was not so very long ago, we may deduce the following proposition. Seen in the perspective of time all statements of the law, whether by the legislature, or by judges, or by jurists, are no more than working hypotheses. They are, quite simply, temporary approximations which some people in their wisdom have found to be convincing at certain points of time.

To the layman, this may appear to be a startling proposition. The layman thinks of the law as inherently predictable, clear, precise, certain, even rock-like in quality. It is, in fact, nothing of the sort. Of course, it is true that, at any given point of time, if a citizen seeks advice from his legal adviser in order to regulate his affairs - to make a will, or buy a house, or even to divorce his or her wife or husband - the lawyer should know or be capable of ascertaining the applicable law and so be able to give his client useful advice. It is also true that a citizen who fears that a proposed course of conduct may infringe the law - may, for example, contravene regulations which control road traffic or the running of factories, or fall foul of the income tax laws - should be able to obtain reasonably clear advice from his lawyer, or even to look up the relevant provisions himself, in order to ensure that his conduct is within the law. But these propositions are entirely consistent with the fact that the law, in the sense of legal principle, is in a continuous state of change; indeed, it is my own belief that, as a general rule, gradual development of the law does not deprive it of such stability as is desirable in order to enable citizens to regulate their affairs or amicably to resolve their disputes.

Why is the law always changing? The first reason is that law itself is a subject of 
great complexity. Since it has to reflect all the untidy complexity of life, it is itself unavoidably complex; and the principles which gradually emerge from the mists of doubt as the preferred principles at any particular point of time are often the product of long debate, and of many judicial decisions on particular facts. Moreover, in the ultimate analysis all principles inter-relate - property, obligation, estoppel and so on cannot be considered in isolation, and still less can their constituent elements - so development in one may have an impact upon another. We should not, therefore, be surprised by the proposition that statements of legal principle are simply working hypotheses. Indeed, our laws not only represent the fallible conclusions of men. There are also - and this is the second factor which stimulates change - subject to the ebb and flow of the tides of fashion and opinion. Moreover, the idea that principles of law are, so to speak, just waiting to be discovered if only we are clever enough to find them - just like some oil field or gold mine or archaeological artefact awaiting the attention of an intelligent and industrious geologist or archaeologist - is entirely mistaken. If that were right, why do not, for example, French and English lawyers come to the same conclusions as to the correct principles applicable to govern contracts and other obligations? Why have we not identified the same institutions for the regulation of rights of property? We have not done so; though some of the differences between us are more apparent than real, being the result not so much of differences of substance, than of using different languages - not merely different linguistically, but different in the sense that we have adopted different legal concepts as our tools of trade. But it is, I believe, indisputable that, in many cases, legal principles are not self-evidently right; there is often a choice, not only in points of detail or in terms of practicable solutions of particular problems, but also in answering more fundamental questions, and the choice of answer may affect the fabric of a particular institution, or even a whole branch of the law. It follows, of course, that there are no instant, complete, solutions; those of us who persuade ourselves that we can perceive such a solution are deceiving ourselves, and, if we as judges attempt to state legal principles in too rigid a form, we inflict upon a living institution a dose of arthritis which will, before long, require the services of a doctor, or even a surgeon, if it is to be restored to health. A statement of principle, capable of qualification to meet unforeseen circumstances and capable of adaptation to absorb developments in other inter-related parts of the law, is generally all that is needed to provide the temporary certainty required to guide citizens in their practical affairs. Absolute certainty in the law is in truth not merely undesirable, but it is, as history shows, a chimera. As I heard Professor Marcel Storme of the University of Ghent say only last month, at the Institute of Advanced Legal Studies, there are no definitive solutions. The only truly constant feature of the law is that it is in a constant state of change.

If it is true that the law is in a constant state of development, and if the judiciary is one of the instruments through which such a development takes place, it is not unreasonable to ask: within what limits are judges empowered to change the law? 
This is indeed a profound question of constitutional importance; though like many questions, especially profound questions, it is not necessarily desirable, or even possible, that it should be answered with any degree of precision. It is usually said that judges cannot legislate; and this is plainly right in the sense that judges should not invent new laws, as does a legislative assembly in a democratic society such as ours. The function of judges is, literally, to decide cases. In deciding cases the prime influence is, and should be, the facts of the particular case. The judicial act can not unreasonably be epitomised as an educated reflex to facts, though always within the framework of established legal principle. But the emphasis must be on the facts, so that the judge must be able, where appropriate, to adapt or even qualify legal principle, even established legal principle, to accomodate the facts of the case before him.

The controlling mechanism under which judges operate in performing their duty of applying legal principles to the cases before them is comprised in what is commonly called the doctrine of precedent. It is usually said that the function of the doctrine of precedent is to achieve certainty in the law. This is, I believe, an over-simplification of a complex matter.

To me, the doctrine of precedent (whatever precise form it may take) has two functions. The first is to ensure stability in the law; and the second is to secure consistency in its administration. Let me explain. We have in England a well-recognised principle that judges are absolutely bound by decisions of superior courts. So with us a High Court judge is bound by decisions of the Court of Appeal, and the Court of Appeal is bound by decisions in the House of Lords. In point of fact, it is remarkable how much freedom is still left, in practice, to judges of inferior courts to achieve practical justice; this is achieved by the use of the well-known technique of distinguishing authorities which otherwise might be thought to inhibit the freedom of action of the inferior court. But that the principle exists is undoubted; and the function of the principle is to ensure consistency in the administration of the law - the effect being that courts of co-ordinate jurisdiction, and expecially inferior courts to which citizens' disputes are directly (and usually, in practice, exclusively) submitted will, generally speaking, apply the same principles of law. I say generally speaking, because we do not find it necessary in England to demand that a judge should be bound by the decision of another judge of co-ordinate jurisdiction; in practice, however, he will nearly always follow it, as a matter of comity.

So much for consistency. But what about stability? Here we are talking not about different judges applying the same principles of law, but about an inhibition on change. This is something quite different. It affects principally the appellate courts, and especially the supreme tribunal of the country. The formal question can thus be stated: to what extent are appellate courts, and especially the supreme tribunal, bound by their own decisions? It used to be true in England, not only of the Court of Appeal, but also of the House of Lords, that they were indeed bound by their own decisions. For a period of about 75 years, corresponding roughly with 
the first three-quarters of this century, the House of Lords proceeded on the basis that it was absolutely bound by its own decisions. That decision has now been abandoned; and surely this is right. At the most simple, practical, level, the proposition that the House of Lords should not be free to review its own decisions presupposes a legislature which is ready and available, at reasonably short notice, to put things right when they go wrong. That is just not so. In democracies, legislatures are not much interested in what may be called lawyers' law. They are interested in advancing policies and, at a cruder level, in gaining, or at least retaining, electoral support. Moreover, legislative changes of lawyers' law involve very difficult questions on how far the legislature should go. So the proposition that the House of Lords was absolutely bound by its own decisions was thoroughly unpractical. But, more fundamentally, it ignored the historical fact of change through judicial development of the law - change which can take place, does take place, and must take place in every system of law if it is to provide a satisfactory response to the reasonable expectations of the citizens of the country. Whatever the theory underlying the old approach of the House of Lords that it should be bound by its own decisions, that theory, like any other, has had to yield to facts. It is far healthier and more realistic to recognise facts, and generalise from them, than it is to propound a constitutional theory and derive from it an inhibition upon the natural processes that in fact take place. If the theory which underlay the old approach was that the judges must not legislate, the answer should be that that statement must be expressed in a qualified form to meet the facts. And if the theory was that the law is a nugget of gold, awaiting discovery, so that, once exposed, it is inevitably right and inevitably permanent, then the answer must be that that is, in point of simple historical fact, untrue.

The real principle which both restricts the judicial power to legislate and ensures a sufficient degree of stability in the law is far more subtle than a rigid rule precluding change, or indeed the doctrine of precedent (whatever its form). It is enshrined in one word - gradualism. This is the true, the ultimate limit on the power of the judges to develop, even change, the law; though it is important to recognise that the principle of gradualism does not totally inhibit innovation. Generally speaking, however, judges do not suddenly invent totally new principles; and when innovation takes place, it is generally as a result of intense pressure of a practical kind. We did not, for example, see the English judges in the nineteenth century suddenly invent a generalised principle of liability in negligence for physical damage to persons and property, despite all the pressures arising from the inventions of the railways, the development of factories, and other consequences of the industrial revolution. What we saw was a gradual development of the law over a period of nearly 100 years, culminating in the decision of a bare majority of the House of Lords in Donoghue v. Stevenson ${ }^{1}$ in 1932; and what we are still seeing in England today is a further gradual exploration of the possible principles which may 
govern liability in negligence for purely economic loss. A similar problem is, of course, troubling our colleagues in Germany and in France.

We must not be surprised that judges have the power to create law. The layman might be forgiven for thinking that that power should be vested only in the elected representatives of the people, i.e. in Parliament; but that is not so, for history shows plainly, beyond all contradiction, that no legal system can operate efficiently without the creative power of the judges. That fact is expressly recognised in Article 1, paragraph 2, of the Swiss Code which provides that "If no applicable provision is contained in the Code, the judge is to apply customary law or, in its absence, the rule which he himself would establish, if he were the legislature." And German jurists have for long openly recognised that, although, according to the notions of the Enlightenment, a code contains an answer to all the questions that may arise in the relevant rubric of the law, such an idea was bound to show cracks before long, as indeed it did. Nowadays, in Germany, it is accepted that judicial interpretation of the Code may go beyond completing the law; it may even alter it against its very words. This is a matter to which I shall revert later in this lecture; I pause only at this stage to observe that it is very difficult to reconcile Montesquieu's doctrine of the separation of powers with the recognition of the judicial power to create law - a fact which I, as a member of Parliament who sits in a judicial capacity, feel able to contemplate with some equanimity.

I return to England. It is now over twenty years since the House of Lords decided, as I would put it, to re-assume the power to review its own decisions. But we have yet to see any coherent statement of a philosophy upon which that power will now be exercised; and indeed I suspect that this reflects a sensible restraint on the part of those concerned. At present we have what appears, at first sight, to be a somewhat startling, even bizarre, situation, which can be caricatured in the following manner: the House of Lords will not reverse a decision of its own which is too young, or one which is too old, but only one which is, so to speak, middle-aged. So stated, the approach does not have much intellectual appeal; and it is right to search for the reasons underlying this attitude so that a more sensible policy can be revealed. The inhibition against reviewing a decision which is comparatively recent reflects perhaps two things: first, a sense that ding dong change is inherently undesirable because it might de-stabilise the law; and second, of more practical importance, a feeling that in common sense terms time has to pass to enable, so to speak, the dust to settle on a decision, to ensure that any reconsideration of the decision will be the product of mature reflection rather than of simple reaction. These are sensible reasons, inhibiting a rapid review of recent decisions but not, be it noted, precluding such a step altogether. Indeed, this reflects actual practice. For I can, and I am sure you can, think of more than one decision of the House of Lords which did not survive for many years in this century.

What is the origin of the inhibition against disturbing a decision which has stood for many years? It cannot, of course, be simple longevity: for age-old decisions 
must, in the fullness of time, be silently consigned to the legal scrap heap. The true reason (putting on one side those cases which have been widely acted upon) is that there is an underlying fear that a decision, if it has stood for many years, may have become so embedded in the mosaic of the law that to reverse it would effect too great an upheaval of legal principle, or at least that the consequences of its reversal cannot be wholly foreseen. This is reasonable, but once again it cannot preclude reversal of any decision, merely because it is old. Indeed, in many cases the effect of the excision of an old authority is predictable, at least in a general sense; and it may well be that it is that very effect which provides the argument for change.

We can find in the Law Reports of the last twenty or thirty years numerous illustrations of the judicial development of the law. Let me glance at some striking examples. We have seen the abandonment of the absolute doctrine of sovereign immunity for a qualified doctrine, in The Phillipine Admiral, ${ }^{2}$ Trendtex Trading Corporation Ltd. v. Central Bank of Nigeria ${ }^{3}$ and I Congreso del Partido ${ }^{4}-\mathrm{a}$ development now, of course, enshrined in a statute. We have seen the acceptance of the principle of forum non conveniens, in cases of stay of proceedings in this country when parallel proceedings have been or should be commenced abroad, in The Atlantic Star ${ }^{5}$ and MacShannon v. Rockmare Glass Ltd.. ${ }^{6}$ We have seen recognition of the principle that both arbitration awards and judgments may be made in foreign currencies, in Jugoslavenska Oceanska Plovidba v. Castle Imvestment Co. Inc. ${ }^{7}$ and Miliangos v. George Frank (Textiles) Ltd. ${ }^{8}$ (in the latter of which cases a by no means elderly decision of the House of Lords, In re United Railways of Havana v. Regla Warehouses Ltd., ${ }^{9}$ was overruled). Even more remarkable, we have seen the judicial creation of new forms of procedure, in the form of the Mareva injunction and the Anton Piller order. The former of these has indeed fulfilled a long-felt need. I think it worthy of record that when, many years ago, the Law Commission wrote round asking for proposals for reform, I and $\mathrm{Mr}$ Brian Davenport, having some experience of the continental jurisdiction in such cases, proposed that the arrest of assets in aid of civil claims might be a topic worthy for consideration; but the Law Commission must have decided, no doubt for good reason, not to pursue the matter at that time. It was, therefore, particularly satisfactory to me that the Courts were prepared to extend the remedy of the injunction to meet this need. More recently we have seen, in Ramsay v. I.R.C. ${ }^{10}$ and Furniss v. Damson, ${ }^{11}$ a profound change in the attitude of the Courts to 
tax-avoidance schemes. But perhaps the most striking change of all has been in the development of a modern system of administrative law, through the remedy of judicial review, in a whole series of landmark cases in the House of Lords notably, Ridge v. Baldwin, ${ }^{12}$ Padfield v. Minister of Agriculture, Fisheries and Food, ${ }^{13}$ Anisminic Ltd. v. Foreign Compensation Commission, ${ }^{14}$ Conway v. Rimmer, ${ }^{15}$ and the GCHQ case - In re the Council of Civil Service Unions and others. ${ }^{16}$

No doubt we could all multiply these examples. But in any event I do not see how it can possibly be said, in the face of examples such as those which I have just given, that judges do not have the power to change the law. As one Master of the Rolls, Sir George Jessel, said many years ago of the rules of equity:

"It is perfectly well-known that they have been established from time to time altered, improved, and refined from time to time. In many cases we know the names of the Chancellors who have invented them. No doubt they were invented for the purpose of securing the better administration of justice, but still they were invented. Take such things as these: the separate use of a married woman, the restraint on alienation, the modern rule against perpetuities, and the rules of equitable waste. We can name the Chancellors who first invented them, and state the date when they were first introduced into Equity jurisprudence; and, therefore, in cases of this kind, the older precedents in Equity are of very little value. The doctrines are progressive, refined and improved; and if we want to know what the rules of Equity are, we must look, of course, rather to the more modern than the more ancient cases."

Sir George Jessel contrasted the rules of equity with the rules of common law, which he said were "supposed to have been established from time immemorial". As his choice of words betrays, this is obviously a fiction; and it is high time that we should take the same realistic view of the development of the common law as Sir George Jessel took of the development of equity. In all truth, as I never tire of saying, it is not only a historical fact that judges do change the law, but it is also an absolute necessity that they should do so, or the law would not be able to satisfy the reasonable expectations of the society which it is the duty of the judges to serve.

But there is an essential corollary of the exercise of this judicial power of change. It is essential that, in seeking to develop the law, the judges should so far as possible operate within the confines of the principle of gradualism. They should consciously allow themselves to be influenced by the facts of the cases which they have to decide, and allow their intuition as lawyers to influence them in adapting or qualifying existing legal principle to achieve the just result in those cases. This is 
the essentially pragmatic approach which is perhaps the most fundamental of all the characteristics of the common law, which is, I believe, shared by all of us who work within that system. Let facts develop principles: do not let principles, still less rules, be so dogmatically stated as to preclude a just decision on the facts. But, if that is right, we must not attempt to decide too much in any particular case. The over-ambitious judge who attempts to re-state the law in broad, even exclusive, terms, is, except in very rare circumstances, doing a dis-service to the legal system. Likewise the judge whose reasoning is too complicated, too convoluted; exercises in personal codification, and over-elaborate reasoning, are to be deplored. But there is a technique at hand for dealing with this mistaken form of judicial activity. This is the technique of the narrow definition of the ratio decidendi of the case, ensuring that each case should be treated in law as no more than a judicial reflex to a particular fact-situation, of course always within the framework of legal principle. So if judges attempt to decide too much, subsequent courts can qualify the decision; and if they use too complicated reasoning, that reasoning can, if appropriate, be unstitched, even unravelled, to allow practical justice to be achieved in a later case. For it is a matter of fundamental importance that no judge, however distinguished, should be allowed in any way to persuade, or even inhibit, the organic growth of the common law.

Even though we must recognise, as a matter of simple historical fact, the power of the judiciary to create law, it is obvious that, in a society as rapidly developing as the one in which we all live today, the judiciary, operating within the confines of the principle of gradualism, is by itself a wholly inadequate vehicle for the reform of the law. Since early Victorian times, we have seen an increasingly active legislature remodelling our institutions, including our judicial system, and reforming substantial areas of our procedural and substantive law. All this is well-known. We all know of the extraordinary work of Jeremy Bentham, who sought to base, upon a single principle, a science of legislation which would lead to a wholly codified system of law and procedure, organised upon rational principles, so that the legislature would be the sole source of the law and the function of Judge $\&$ Co. would be reduced to the literal interpretation of the statutory text. We can see, in the perspective of time, that this was an unrealistic, indeed impossible, dream; but we can also see how very productive his work was in the sense that it led, in the hands of other, more practical, men, to innumerable practical reforms of all kinds. But, although it produced, through the Indian Law Commission under Macaulay, notable Indian codifications in the form of the Indian Penal Code and the Indian Contract Act, there was no sweeping codification of the law in this country, though there were, of course, the limited codes in the field of commercial law - sale of goods, partnership, bills of exchange and marine insurance. The Indian legislation was doubtless of great value in introducing new, uniform, laws to a vast sub-continent; but when we read it today, we can see how dated a codification will become over a period of only one century, and how dead a hand it can lay upon the law unless the courts are permitted, and adopt, a very free hand in 
its interpretation and development. For example, Chapter V of the Indian Contract Act of 1872, entitled "Of Certain Relations Resembling Those Created By Contract", is the only place where we can find any source for what we nowadays call the law of restitution; and of the five sections in that Chapter, one is irrelevant to restitution, three are concerned with minor topics, and from one alone (section 72), consisting of a single sentence, would have to be derived the greater part of the law of restitution. A parallel can be drawn with Articles 1382-1386 of the French Code Civile, from whose meagre provisions was developed the French law of delict.

It was not until the enactment of the statute establishing the Law Commissions in 1965 (characteristically, bodies foreshadowed by Jeremy Bentham) that we see the establishment of institutions entrusted with the systematic development and reform of the law in the United Kingdom. Such development and reform was expressly stated, in the statute, to include "in particular the codification" of the law. Consistently with that expressed statutory purpose the English Law Commission included, in its initial programme, ambitious projects for the codification of the law of contract and the law of landlord and tenant. Yet, twenty years later, no draft code on either subject has seen the light of day; and it is likely that both projects have quietly been put on one side. There are probably many reasons for this. One is that attempts were being made to codify the law on subjects of extreme complexity in too precise a form; in other words, the vice of statutory draftsmanship in England was inhibiting the codification of the law. Another is that the projects proved to be far more difficult than was anticipated. But another, and probably more profound, reason is that in truth codification has been perceived to be unnecessary. Just as constitutions are the children of revolutions, so also are codes, though the word revolution has in this context to be given a broader meaning. The French Code Civile was the child of the French Revolution, or at least of the Napoleonic period which followed it. The German BGB was a product not only of the Age of Enlightenment, but also of the unification of Germany under the Prussian monarchy. At another level, countries seeking to change their own societies have imported codes from overseas: France has done a great export trade in law, and notable example of countries which have drawn upon the German codifications are Turkey and Japan. I have already referred to the introduction of the Indian Penal Code and the Indian Contract Act, introduced to achieve a unified criminal and commercial law in the Indian sub-continent. At a more humble level, we can see in this country examples of fundamental change being wrought in particular areas of the law by codification: a classic example in England is the fundamental change made in recent years in our law of divorce, with the abandonment of the concept of the matrimonial offence and the substitution of the concept of the irretrievable breakdown of the marriage, which was achieved by a statutory re-statement of the law relating to matrimonial causes. There are of course many other examples.

We are all greatly indebted to the Law Commission in this country for the 
manner in which it has approached its work. Under a series of distinguished Chairmen, we have seen no rush for spectacular reforms, but rather have we seen a series of proposals founded upon wide consultation and careful research, informed by serious scholarship, which have led to a substantial number of reforms, and on occasion (the recent paper on the so-called Parol Evidence Rule provides a striking example) a refusal to be inveigled into unnecessary or undesirable change. Regret is sometimes expressed that they have not been able to move faster; but this is probably a disguised tribute to the quality of their work. The great advantages of this method of developing the law have been eloquently described by Dr Peter North in his Colston Lecture of 1984, the basis of a paper published last year in the Journal of the Society of Public Teachers of Law, Legal Studies. For example, it does not depend upon the accidents of litigation; it can take account, through consultation and research, of wide-ranging policy issues - a point which recalls to my mind the decision of the House of Lords in Anna v. Merton London Borough Council, ${ }^{17}$ the principal effect of which appears to have been the pouring of enormous quantities of unnecessary concrete into the ground, at very considerable expense to the community, running possibly to millions of pounds each year; and a third advantage is that it need not be retrospective in effect. We have, however, to recognise, with Dr North, that all methods of developing the law have both their advantages and their disadvantages and great care must be taken, not only in proposing a particular change, but also in deciding whether to use a particular vehicle for such change. Today, I wish only to draw attention to one serious danger and one serious disadvantage of statutory law reform. The danger is that piecemeal legislation may exercise a distorting effect on the development of the law. This danger is, I believe, generally recognised by the Law Commission. Speaking of the law of restitution, in which I have a particular interest, I was glad when they decided (unlike certain Canadian colleagues of theirs) to desist from considering reform of the recovery of payments made under a mistake of law; and, like Professor Birks, I have been anxious about their proposal for reform of the law relating to recovery of money paid by parties who are in breach of contract. I cannot help remembering the Law Reform (Frustrated Contracts) Act 1943 and the problem which faced me in B.P. v. Hunt ${ }^{18}$ in relating the provisions of that statute (mercifully drawn, on the express direction of Viscount Simon, in very broad terms) to a law of restitution now far more developed than it was in 1943. But the one serious danger is of a more profound kind. It is that the product of the labour of the Law Commission must take the form of legislation. This has two consequences. The first is that, as every competent jurist must know in his heart of hearts, mistakes will inevitably be made though every care is taken, and new circumstances will occur, new cases will emerge, which have not been, and maybe could not be foreseen. I know full well, 
from my own work as judge and jurist, that practically every statement of principle which I utter is subject to mental reservations, sometimes great, sometimes small; and that the more fundamental the principle, the more likely are there to be reservations, and the more important are such reservations likely to be. The second consequence is that statutory law reform is likely to lead to ossification of the law, precluding gradualist development which is capable of ironing out those wrinkles with which old age disfigures law, like all living creatures. This is especially true of English style statutes, with their tight, precise, draftsmanship, and their obvious "hands off" to judicial busybodies who may be anxious to do justice in cases unforeseen by the draftsman, perhaps inspired by a supposed judicial antipathy to statutes, which, in my own experience as a barrister and a judge, is wholly illusory. This type of draftsmanship is, no doubt, one of the reasons why the Benthamite ideal of codification for its own sake has generally been abandoned, thus illustrating most vividly the truth that Parliament cannot enact a philosophy, as it purported to do in the Law Commissions Act. Nowadays, only when a substantial specific advantage is perceived to accrue from codification, which outweighs its inherent disadvantages, is codification likely to be acceptable in England. And, in a relatively stable country, that substantial advantage is likely to consist of a need for substantial reform of the relevant rubric of the law.

It is in this context that the proposed codification of the criminal law in England has to be judged. The draft code, which will relate only to serious crimes, has been commended to us on the basis that it will make the criminal law more accessible, comprehensible, consistent and certain. Like many general statements of this kind, this statement of aims has a most attractive ring; but it has to be subjected to critical analysis. I must confess that, when I first read it, it sounded to me like yet another attempt to advocate codification for its own sake; and I was immensely pleased to hear Professor Smith, the first of the Three Wise Men to whom we owe so great a debt for having dedicated so much skill and time to produce this admirable draft for our consideration, say in his Child \& Co. Lecture in London earlier this year that he himself did not believe in codification for codification's sake. So the new draft Code will have to be justified on its own merits; and, first of all, an explanation will have to be given why no codification is proposed for Scottish criminal law, to which the English Law Commission's statement of aims is equally applicable. The debate has only just begun. It would not be appropriate for me to dwell upon the subject in this lecture.

There is no doubt that the strongest evidence for rejecting the Benthamite ideal of codification for its own sake is to be found in the experience of codified systems on the continent of Europe. This proposition can best be illustrated by the famous Article 242 of the BGB which reads (in translation) as follows:

"The debtor is obliged to perform in such a manner as good faith requires, regard being.paid to general practice." 
This innocent-sounding provision has been used to create a whole equity, to mitigate the rigours of the Code; the comparison with the Chancellor's equity in this country is too strong to be ignored. German jurists have stated that Article 242 embodies a principle of legal ethics, which dominates the entire legal system; it has also been described as the gateway for natural law to enter the BGB; yet again it has been said that the extremely numerous decisions under Article 242 are more comparable with the case law in the Anglo-American systems than anything else in German law. Perhaps the most famous decision under Article 242 is the decision of the Reichsgericht in 1923 ( $R G Z$ 107, 78, 86), during the period of hyperinflation in Germany, to revalorise mortages in terms of the value of money at the time of their creation - a decision of such strength that it must take the breath away from even the most pragmatic common lawyer. I have not time to do more than glance at this fascinating topic; but to me it illustrates more than anything else the absolute need, in every legal system, to allow judges the freedom to develop the law both creatively and pragmatically, if the legitimate expectations of citizens are to be fulfilled.

But, in any event, the ground has been cut from under the feet of the Benthamite movement for codification in this country by the growth in stature of the English jurist of the past century. Until the second half of the nineteenth century, there was no systematic instruction in the common law in the English universities. A man who aspired to be a lawyer entered into an apprenticeship, and learned his trade at the elbow of his master in the law - whether barrister or solicitor or attorney. But in the late nineteenth century, law faculties began to develop in the Universities of London, Oxford and Cambridge, and gradually also in other universities through the country, especially after the end of the Second World War. In consequence, the number of academic lawyers has dramatically increased. During this period, we have seen the growth of the legal textbook. It is difficult nowadays to imagine the difference between a practitioner's library of 1886 and one of 1986 . In 1886 there were very few legal textbooks available, apart from practitioners' manuals. Today there are innumerable textbooks published on every subject. Obviously, some have a strongly practical slant, and many are still composed or edited by practitioners; but many, and especially those of the highest quality, are the work of academic lawyers, sometimes lawyers of the highest distinction. Every competent practitioner has textbooks at his elbow as he works in court, or in barristers' chambers or in solicitors' offices. But the influence of the jurist does not stop there. With the growth of law faculties in the universities, we have seen the development of what is now called the academic stage of legal education within the universities, and indeed polytechnics, all over the country; and today over three-quarters of those who enter the profession of law in England, whether as barristers or solicitors, will have taken a law degree. It follows, of course, that during their most impressionable and formative years, these young men and women will have come under the influence of their law teachers and of their writings, both in books and in law journals. This too provides a stark contrast 
with the state of affairs of 100 years ago - or even 50 years ago, just before the war. In the old days, it was not thought that law was a suitable subject for a liberal education; the best minds studied classical literature in the Latin and Greek languages, philosophy, ancient history - modern history, English literature, economics and the sciences were admitted to the club only in relatively recent years. But law was regarded as technical, black letter learning, more suitable for apprenticeship in a practitioner's chambers. All that has changed. It is now recognised that law is in itself an admirable subject for university study, combining both rigorous mental discipline and, if the structure of the course is sound, an element of history and an introduction both to philosphy and to social science.

It is difficult to overestimate the influence of the jurist in England today - both on the formation of the view of young lawyers and in the development of the law. Indeed, we now live in the age of the legal textbook. It is the textbook which provides the framework of principle within which we work. The prime task of the jurist is to take the cases and statutes which provide the raw material of the law on any particular topic; and, by a critical re-appraisal of that raw material, to build up a systematic statement of the law on the relevant topic in a coherent form, often combined with proposals of how the law can beneficially be developed in the future. There has thus been provided for all lawyers, practitioners and students, an established framework for the consideration of each problem as it arises. There has grown up a common understanding of principle, which facilitates a discussion of each problem, and indeed the decision of each case in court. I find it difficult to imagine how I could carry on my work without modern legal textbooks, many of which are of an astonishingly high quality. And it is interesting to observe that this is as true of subjects which are codified, as it is of those which are not. If I have a problem on the sale of goods, I turn straight to my copy of Benjamin on Sale, despite the existence of the Sale of Goods Act; just as, if I have a problem on the conflict of laws, I turn straight to my copy of Dicey and Morris. With the benefit of textbooks of this quality, codes are, generally speaking, unnecessary; they are surplus to requirements. For all practical purposes, textbooks are as informative as any code could be, indeed more so; and they lack all the defects of codes, since they can be changed without difficulty as the law develops, and they encourage, rather than inhibit, the gradual development of the law. To put it shortly; propositions of law in a textbook need not aspire to completeness; they may be expressed to be subject to doubt; they may be changed without legislation; and judges are at liberty to depart from them, if persuaded that it is right to do so.

It is likely, however, that the next period of our legal history will see the growth of a new influence upon the development of the law. I refer to the growing importance of comparative law. In the nineteenth-century, English lawyers saw comparative law essentially in historical terms, as we can see evidenced especially by the work of Sir Henry Maine. But in the twentieth century, fostered by French and more especially by German scholars, we have seen the growth of an ideal that civilised societies should be enabled, for their mutual benefit, to share the same 
principles of law, especially in private law affecting individuals who nowadays move freely among different countries and who transact an increasing volume of business. At first, it was thought that it was only possible to compare systems of law which shared a common basis of principle; and for that reason, comparative study tended to be confined to those systems which, to a greater or lesser degree, were derived from Roman law. The common law, with its entirely separate legal history, tended to be excluded. But, especially since the Second World War, with the expansion of legal scholarship, with the settlement of distinguished German Jewish scholars in England and their enrichment of our culture, with the spread of the English language throughout the free world and, as a result, the readier availability of English sources to continental scholars, and with visits of continental scholars to generous and hospitable American universities - with all these things, we have seen a marked change; and nowadays, comparative study tends to embrace all the legal families of the world. Indeed, the common law family, not only because of its enormous size and influence, but also because of its rich and separate history, exerts a peculiar fascination upon, in particular, German scholars. Yet another influence towards comparative study has come from the accession of the United Kingdom to the European Economic Community, with its programme for unification of the law; and to some extent also the development of International Conventions, notably in the fields of Maritime Law and of International Sale of Goods, has contributed to the movement. But, as I gaze into the crystal ball, it is not in the adopting of binding uniform laws that I see the most fruitful developments in this area. For uniform laws are more usually the result of economic and political pressures, even of sheer horse-trading, than of rational acceptance of optimum solutions. I see the most fruitful development in the work of scholars, as jurists from each of the great legal families of the world learn more and more about each other's systems and gradually perceive in particular areas the advantages and disadvantages of each. It is not, I think, difficult to approach the study of comparative law with a degree of objective detachment from one's own legal system: indeed, it is a remarkable fact that the study of the legal system of another country enables a lawyer to learn more about his own. It is, I think, even possible that there will develop among comparative lawyers some degree of consensus as to where, for example in the law of contract, the most desirable principles are to be found. In this way, just as the American Law Institute has published Restatements of the Law which, though not binding, have provided a unifying influence upon the differing legal systems applicable in each State of the United States, so we may see the publication of works by European comparative lawyers of a similar kind in which, no doubt with considerable qualifications, some selection may be made of the most desirable principles which might be generally applicable in various branches of private law.

At all events, in whatever form the development takes place, we are, I think, bound to see an enrichment of our legal culture on an unparalleled scale through the increasing study of comparative law. Indeed I like to think that, in the future, 
the best English legal textbooks will cease to be critical statements only of English law and that they will no longer rely only on English sources. The modern English jurist tends to specialise closely in the study of one or two subjects. If, as I hope and expect, he extends his vision to the study of those subjects as treated in other systems of law, his statement of English law can, and should be, set, to some extent at least, in a comparative context. In this way, practitioners in common law countries, and especially judges in those countries, will be exposed to new ideas which will not only enrich their understanding of their own law, but may influence them to develop it in ways which previously might not have been thought possible.

The dominant influence of the jurist in the development of the law is in this way likely to acquire new strength. But it is essential that judge and jurist should not only in fact co-operate in their work of development of the law; but that they should perceive that it is inevitable and desirable that they should do so. If judge and jurist - and I include in the latter expression not only those who work at universities and polytechnics, but also those who labour at the Law Commission if they can understand and recognise each other's respective functions, if they can regard each other's work with mutual respect and each other's problems with mutual sympathy and understanding, then the future can be bright indeed. And if, as I believe we can, we add to co-operation between judge and jurist a greater readiness to learn from the legal systems of other countries, not only in the common law world, but also in the civil law countries, then the common law may be about to embark upon the most fruitful period of development in its long, eventful, history.

I began this lecture with a quotation from Pope Gregory the Great's correspondence with St Augustine. Let me end with another. Among the questions which St Augustine posed to Pope Gregory was the following:

"Since we hold the same Faith, why do customs vary in different Churches? Why, for instance, does the method of saying Mass differ in the Holy Roman Church and the Churches of Gaul?"

Pope Gregory's reply was as follows:

"My brother, you are familiar with the usage of the Roman Church into which you were brought up. But if you have found customs, whether in the Church of Rome or of Gaul or any other that may be acceptable to God, I wish you to make a careful selection of them, and teach the Church of the English, which is still young in the Faith, whatever you have been able to learn with profit from the various Churches. For things should not be loved for the sake of places, but places for the sake of good things. Therefore select from each of the Churches whatever things are devout, religious, and right; and when you have bound them, as it were, into a Sheaf, let the minds of the English grow accustomed to it." 
If I may transpose that passage from the context of religion to the context of law, then I would say, in the words of some Dickensian character - I forget which them's my sentiments entirely; though Bede himself would simply have added, devoutly, Amen. 